\title{
Spatial Changes in Wetland Configuration of Akure South Local Government Area of Ondo State, Nigeria
}

\author{
Omodehin Adenike Oluwakemisoye*, Basorun Joseph Omoniyi, Oyinloye Michael Ajide
}

Department of Urban and Regional Planning, Federal University of Technology, Akure, Nigeria

\author{
Email address: \\ oaomodehin@futa.edu.ng (O. A. Oluwakemisoye) \\ ${ }^{*}$ Corresponding author
}

\section{To cite this article:}

Omodehin Adenike Oluwakemisoye, Basorun, Joseph Omoniyi, Oyinloye Michael Ajide. Spatial Changes in Wetland Configuration of Akure South Local Government Area of Ondo State, Nigeria. Urban and Regional Planning. Vol. 6, No. 3, 2021, pp. 87-92.

doi: $10.11648 /$ j.urp.20210603.11

Received: June 22, 2021; Accepted: July 20, 2021; Published: July 29, 2021

\begin{abstract}
Wetlands are not wastelands as believed in time past but areas of land that play important roles in climate change mitigation through conservation and preservation; poverty alleviation through job creation; as well as food security through sustainable wetland agriculture. The importance of wetlands cannot be overemphasized, hence the need to use them wisely and sustainably. However, despite the important roles played by wetlands, wetland resources are still endangered by increase in population, rapid urbanization, mining and pollution among others. This study is aimed at examining the spatial changes in wetland configuration in Akure with a view to providing information that will enhance sustainable development of wetlands in the city. Remote Sensing and Geographic Information System (RS \& GIS) techniques was used to do a land use classification of the study area to determine the extent of the change in the spatial configuration of wetlands over a period of 33 years using 1986 as the base year; 1999, 2009 and 2019 as the cardinal years. The study revealed a rapid increase in built up throughout the study period, a decline in vegetation and rock outcrop and both increase and decline of wetlands at varying times. During the 2009-2019 periods, wetlands increased substantially to $106.16 \mathrm{~km}^{2}$ which is a significant portion of the study area but with clear indications of possible encroachment and degradation in the future if developments are not controlled. The study therefore recommends proper monitoring and control of developments in the study area and suggests the use of wetland zones as green belts in form of wetlands vegetation or agriculture.
\end{abstract}

Keywords: Wetlands, Sustainable Development, Wise Use, Spatial Changes, GIS

\section{Introduction}

Wetlands are marshy areas made of soil and water. They are places where water meets land; found from the coast to the mountains [22], covering about $7 \%$ of the earth's surface [1]. They are not wastelands as believed in time past; but wealth lands that play a significant role in poverty alleviation [6]. Wetland ecosystems, including rivers, lakes, floodplains and marshes provide many services that contribute to human wellbeing and poverty alleviation [5]. WWT Consulting opines that wetlands are essential for human health and prosperity providing us with fresh water, ensuring our food supply, sustaining biodiversity, protecting against flooding, and storing carbon dioxide [22]. Mohammed sees wetlands as the life wires to many economic activities such as crop cultivation, fishing, livestock rearing etc [6].
The importance of wetlands cannot be overemphasized especially in the wake of climate change; Gannaway posited that wetlands are vital parts of a watershed whose loss and degradation will not only affect the existence and health of an individual wetland and cause local suffering, but also affects the ecosystem as a whole and can contribute to regional and even global environmental problems [3]. Xu, et. al maintained that wetlands play an irreplaceable role in regulating the global climate, maintaining the global hydrological cycle, protecting the ecosystem diversity, and safeguarding human welfare and bringing direct economic values to human beings [23]. Loss of wetlands will therefore contribute to regional and even global environmental problems. Strengthening of efforts to protect and safeguard the world's cultural and natural heritage is one of the targets of the Sustainable Development Goal (SDG) 11 which 
focuses on cities with the goal that by 2030 cities and human settlements are inclusive, safe, resilient and sustainable [19]. Wetlands which are natural heritage therefore need to be protected, safeguarded and utilized sustainably.

Wetlands can be found in strips and in large quantities all over the earth surface covering about $28000 \mathrm{~km}^{2}$ which is about $3 \%$ of the $923,768 \mathrm{~km}^{2}$ land surface area of Nigeria [2; 18]. This submission is in line with that of Orimoogunje and Tijani, et. al. on how richly endowed Nigeria is, both with coastal and inland wetlands [12;17]. They however went further to say that these wetlands resources are currently being threatened by anthropogenic and bio-geophysical factors such as increased population pressure, rapid urbanization, mining and pollution among others. Numbere maintained that globally, more than half of the swhart of mangroves and swamps have been lost [9].

In Akure, Wetlands are scattered across the town along rivers Ala and Elegbin, the two major rivers passing through the city. Being an administrative city and the seat for many governmental organizations and industries in Ondo state, it is fast becoming urbanized and has experienced rapid increase in its population from 71,106 in 1963 to 360, 268 in 2006 as recorded in the 1963 and 2006 Population Census Reports of the National Population Commission (NPC) respectively. This increasing population puts tremendous pressure on land availability as well as food and other social amenities in the city with priority given to developers for buildings rather than for conservation or for agriculture thereby leading to encroachment of the wetlands and consequently degradation.

Olajuyigbe, et. al observed that quite a substantial proportion of wetlands in Akure have been committed into various uses including dumpsites and housing construction with little or no plans for conservation [10]. This encroachment of wetlands could bring about environmental problems such as climate change, flooding, spread of diseases through insects breeding and various forms of environmental pollution within the city. This study examines the spatial changes in the configuration of wetlands in Akure South Local Government Area of Ondo State using Remote Sensing and Geographic Information System (RS \& GIS) techniques to do a land use classification of the study area to determine the extent of the change in the spatial configuration of wetlands over a period of 33 years using 1986 as the base year; 1999, 2009 and 2019 as the cardinal years, with a view to providing information that will enhance sustainable development of wetlands in Akure.

\section{Literature Review}

Wetlands as defined by the United States Environmental Protection Agency (USEPA) are areas where water covers the soil, or is present either at or near the surface of the soil all year or for varying periods of time during the year, including during the growing season [20]. Wetlands can be coastal wetlands or inland wetlands; they include rivers, lakes, floodplains and marshes and provide many services that contribute to human wellbeing and poverty alleviation [5]. Wetlands are found in and around cities making cities liveable by their ability to absorb flood waters from storms, rivers, ponds, lakes, marshes and heavy rainfall as well as the presence of Mangroves, salt marshes and coral reefs which form buffers that protect coastal cities during storms surges [16]. A study by Narayan, et. al. revealed that flood damages from Hurricane Sandy worth more than \$625 million was avoided because of the coastal wetlands along the east coast of the United States (US) [8; 14].

The ability of wetlands to hold water and nutrients makes it function as a water filter that absorbs harmful toxins, pesticides and industrial waste from water thereby filtering the water that goes into ground water aquifers, replenishing it and improving water quality [16]. The presence of abundant water and rich plants makes wetlands produce moist air which naturally provides a cool atmosphere and helps to bring relief to tropical and extremely arid regions hence improving urban air quality.

Ramsar opined that urban wetlands are natural green spaces where city residents can relax and enjoy access to nature which has the ability to improve their physical and emotional health so wetlands can be said to promote human well-being [16]. Wetlands also attracts tourists to swim or bird watch and serves as a source of income for wetland farmers, provides wood for building, reeds for weaving, plants and fruits for medicinal purposes [16].

Ramsar states that the many benefits and services provided by wetlands are essential if the Sustainable Development Goals (SDGs) would be achieved and suggests the wise and sustainable use of wetlands as critical tools for countries to achieve their SDG targets [14]. Wetlands International reported that all major global policy agreements conclude that wetlands are vital ecosystems in the landscape and are indispensable to achieve a sustainable and secure world [21]. The Ramsar's 4th Strategic Plan (2016-2021) presents a vision that wetlands are conserved, wisely used, restored and their benefits are recognized and valued by all [15].

Incorporation of wetlands in urban planning, minimising encroachment on wetlands and rehabilitating wetlands in cities and their surrounding landscapes reduces water risks and safeguards valuable wetland services [21]. Ramsar recognizes that wetlands in all parts of the world play an important role in disaster risk reduction if the wetlands are effectively managed and restored where necessary [15]. Several studies have been done on land use land cover change in Akure but only a few streamlined to the importance of conservation and preservation of wetlands in Akure South Local Government Area of Ondo State to ensure sustainability, this study therefore seeks to fill in this gap.

\section{Method}

Being a trend analysis study, Geographic Information System and Remote Sensing (GIS \& RS) techniques was used to do a land use classification of the study area to determine the extent of the change in the spatial configuration of wetlands over a period of 33 years using 1986 as the base year; 1999, 2009 and 2019 as the cardinal 
years. The rate of change in wetlands was determined using ArcGIS 10.5. The satellite imagery of the study area which is Akure South local government area of Ondo state was obtained and delineated using Google Earth Imagery, it was thereafter digitized into a polygon feature class using ArcGIS 10.5. Landsat satellite images of the study area were acquired for four (4) years: Thematic Mapper ( ${ }^{\mathrm{TM}}$ ) of 1986 and 1999; Enhanced Thematic Mapper (ETM) of 2009 and 2019. The images were made to pass through processes of image enhancement, geo-referencing, re-sampling, image classification and digitization and then overlaid on the spatially disaggregated land cover dataset and on the historical Landsat datasets for the four (4) years with 1986 as the base year and 1999, 2009 and 2019 as the reference years. A supervised classification was performed on false colour composites (band 4, 5 and 7) into the four (4) land use/land cover classes which are: built-up area, vegetation, wetland and rock outcrop.

\section{Result}

The study revealed as shown in table 1, figures $1 \mathrm{a}, \mathrm{b}, \mathrm{c}, \mathrm{d}$ and 2 that spatial configuration of wetlands in the study area varies for the different years examined. In 1986, which is the base year, wetlands in the study area had a land area of 98.90 $\mathrm{km}^{2}$ representing $30.13 \%$ of the total land area, in 1999 , wetlands configuration increased to $120.32 \mathrm{~km}^{2}(36.65 \%)$ and decreased to $90.33 \mathrm{~km}^{2}$ in 2009 (27.52\%); in 2019, there was an increase to $106.16 \mathrm{~km}^{2}$ representing $32.34 \%$. Built up had a steady increase from $14.06 \mathrm{~km}^{2}(4.28 \%)$ in 1986 to $27.01 \mathrm{~km}^{2}$ $(8.23 \%) 36.78 \mathrm{~km}^{2}(11.20 \%)$ and $63.28 \mathrm{~km}^{2}(19.28 \%)$ in 1999 , 2009 and 2019 respectively. Rock outcrop initially had an increase from $18.91 \mathrm{~km}^{2}(5.76 \%)$ in 1986 to $27.61 \mathrm{~km}^{2}$ in 1999 and then experienced decrease to $15.09 \mathrm{~km}^{2}$ and $11.43 \mathrm{~km}^{2}$ (3.48\%) in 2009 and 2019 respectively. There was reduction in the vegetation from $196.40 \mathrm{~km}^{2}(59.83 \%)$ in 1986 to 153.33 $\mathrm{km}^{2}$ in 2009 , a decrease to $186.07 \mathrm{~km}^{2}$ and $147.40 \mathrm{~km}^{2}$ (44.90\%) in 2009 and 2019 respectively.

Table 1. Statistical Result of Landuse/Landcover classification from 1986 to 2019.

\begin{tabular}{|c|c|c|c|c|c|c|c|c|}
\hline \multirow{2}{*}{$\begin{array}{l}\text { Landuse/Landcover } \\
\text { Type }\end{array}$} & \multicolumn{2}{|l|}{1986} & \multicolumn{2}{|l|}{1999} & \multicolumn{2}{|l|}{2009} & \multicolumn{2}{|l|}{2019} \\
\hline & Area $\left(\mathrm{Km}^{2}\right)$ & Percentage (\%) & Area $\left(\mathrm{Km}^{2}\right)$ & $\begin{array}{l}\text { Percentage } \\
(\%)\end{array}$ & Area $\left(\mathrm{Km}^{2}\right)$ & Percentage (\%) & Area $\left(\mathrm{km}^{2}\right)$ & Percentage (\%) \\
\hline Built Up & 14.06 & 4.28 & 27.01 & 8.23 & 36.78 & 11.20 & 63.28 & 19.28 \\
\hline Vegetation & 196.40 & 59.83 & 153.33 & 46.71 & 186.07 & 56.69 & 147.40 & 44.90 \\
\hline Wetland & 98.90 & 30.13 & 120.32 & 36.65 & 90.33 & 27.52 & 106.16 & 32.34 \\
\hline \multirow[t]{2}{*}{ Rock outcrop } & 18.91 & 5.76 & 27.61 & 8.41 & 15.09 & 4.59 & 11.43 & 3.48 \\
\hline & 328.27 & 100.00 & 328.27 & 100.00 & 328.27 & 100.00 & 328.27 & 100.00 \\
\hline
\end{tabular}

Author's field work, 2021.

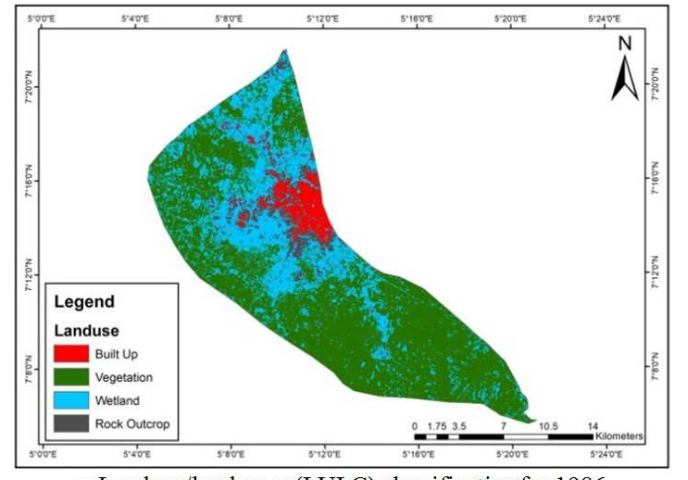

a: Landuse/landeover (LULC) classification for 1986

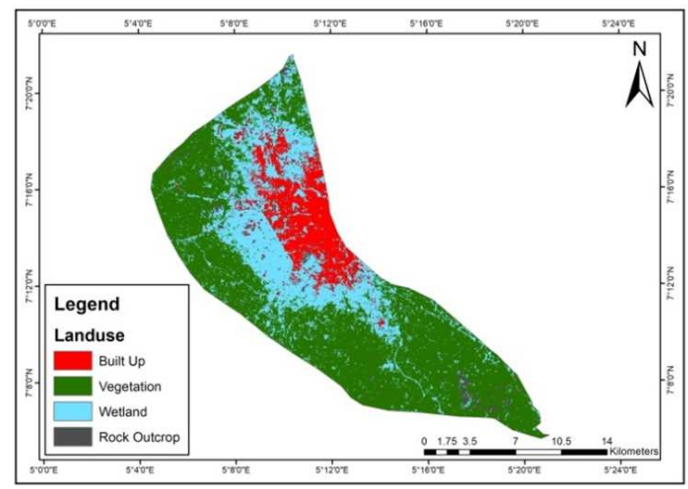

c: LULC classification for 2009

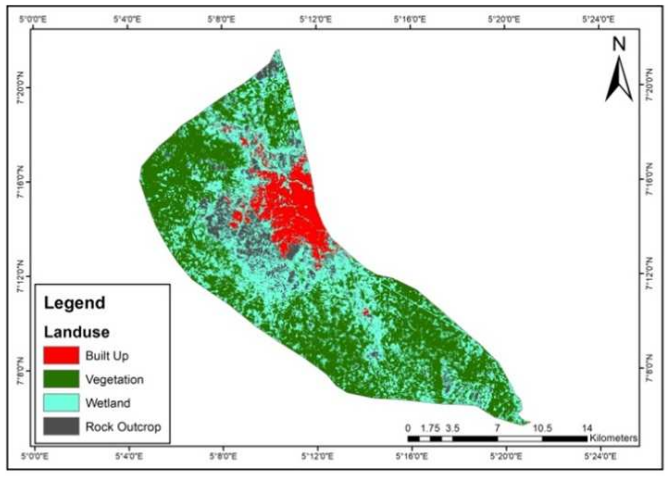

b: LULC classification for 1999

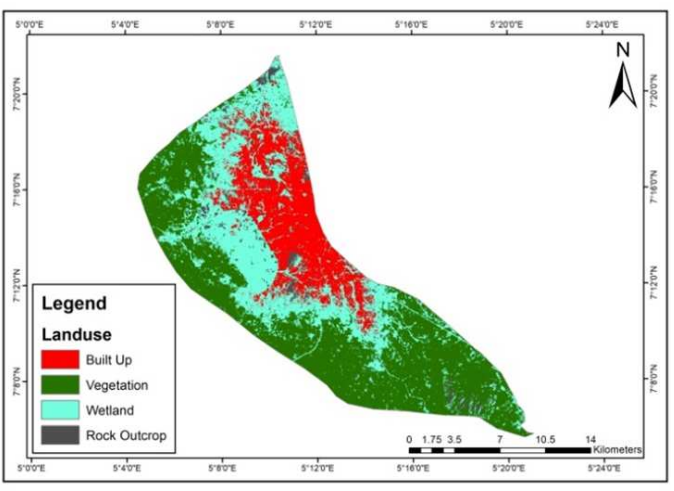

d: LULC classification for 2019

Author's fieldwork, 2021.

Figure 1. Land use land cover maps for 1986, 1999, 2009 and 2019. 


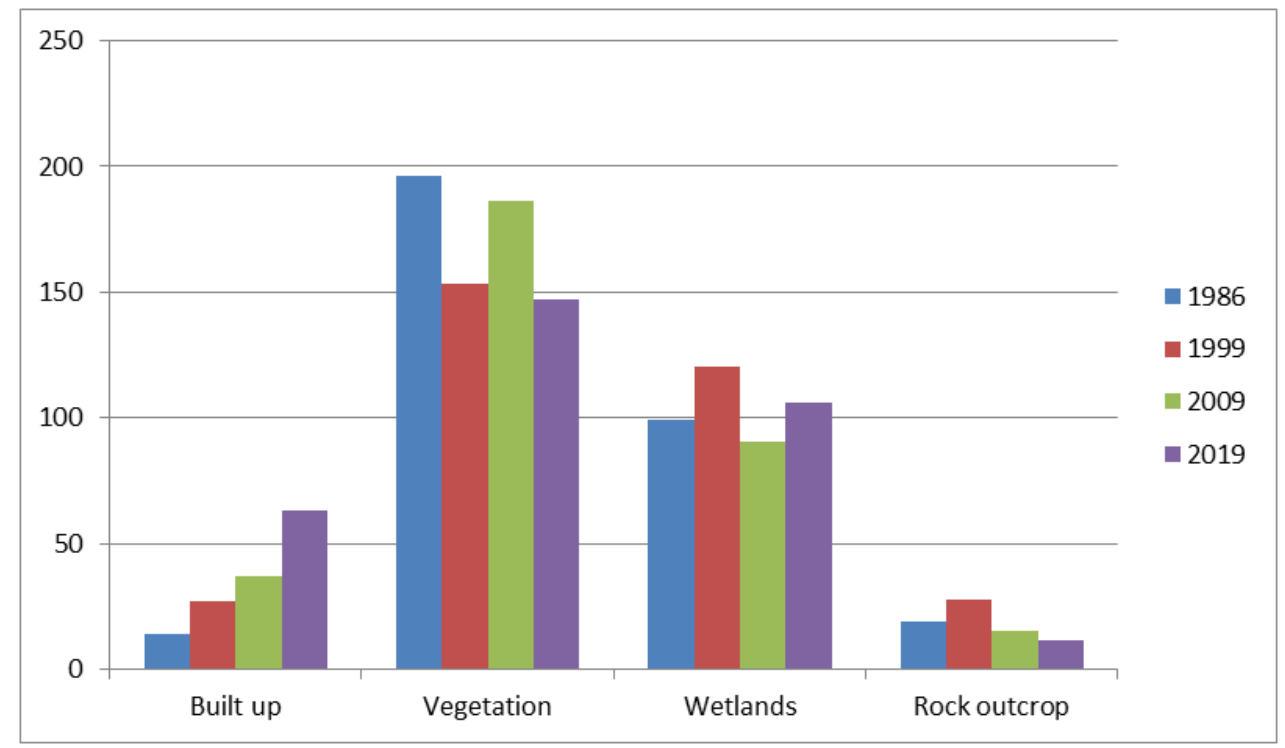

Author's field work, 2021.

Figure 2. Statistical Result of Landuse/Landcover classification from 1986 to 2019.

\section{Discussion}

It is evident from the maps and statistical results that Built Up is the only one out of the four dominant land use and land cover types examined in the study that experienced increase all through the study years. Vegetation, Wetlands and Rock outcrop had both increases and decreases in their spatial configuration. Table 2 shows the details of the changes that occurred within the study years which was grouped into 3 periods; these are 1986-1999, 1999-2009 and 2009-2019 periods.

Table 2. Changes in area statistics of Landuse/landcover classifications from 1986 to 2019.

\begin{tabular}{|c|c|c|c|c|c|c|c|c|c|c|}
\hline \multirow{3}{*}{$\begin{array}{l}\text { Landuse/Land } \\
\text { cover Type }\end{array}$} & \multicolumn{4}{|c|}{ 1986-1999 Period } & \multicolumn{3}{|c|}{ 1999-2009 Period } & \multicolumn{3}{|c|}{ 2009-2019 Period } \\
\hline & 1986 & 1999 & Change & & 2009 & Change & & 2019 & Change & \\
\hline & Area $\left(\mathrm{Km}^{2}\right)$ & Area $\left(\mathrm{Km}^{2}\right)$ & $\left(\mathrm{Km}^{2}\right)$ & $(\%)$ & Area $\left(\mathrm{Km}^{2}\right)$ & $\left(\mathrm{Km}^{2}\right)$ & $(\%)$ & Area $\left(\mathrm{Km}^{2}\right)$ & $\left(\mathrm{Km}^{2}\right)$ & $(\%)$ \\
\hline Built Up & 14.06 & 27.01 & 12.95 & 92.11 & 36.78 & 9.77 & 36.17 & 63.28 & 26.5 & 72.05 \\
\hline Vegetation & 196.40 & 153.33 & -43.07 & 21.93 & 186.07 & 32.74 & 21.35 & 147.40 & -38.67 & -20.78 \\
\hline Wetland & 98.90 & 120.32 & 21.42 & 21.66 & 90.33 & -29.99 & -29.99 & 106.16 & 15.83 & 17.52 \\
\hline Rock outcrop & 18.91 & 27.61 & 8.7 & 46.01 & 15.09 & -12.52 & -45.35 & 11.43 & -3.66 & -24.25 \\
\hline
\end{tabular}

Author's field work, 2021.

During the 1986-1999 period, built up, wetlands and rock outcrop had increase of $12.95 \mathrm{Km}^{2}, 21.42 \mathrm{Km}^{2}$ and $8.7 \mathrm{Km}^{2}$ respectively while vegetation had a decline of $43.07 \mathrm{Km}^{2}$. In the 1999-2009 period, built up and vegetation gained 9.77 $\mathrm{Km}^{2}$ and $32.74 \mathrm{Km}^{2}$ respectively while wetlands and rock outcrop experienced decline of $29.99 \mathrm{Km}^{2}$ and $12.52 \mathrm{Km}^{2}$ respectively. During the 2009-2019 period, built up increased again by $26.5 \mathrm{Km}^{2}$, wetlands gained $17.52 \mathrm{Km}^{2}$ while vegetation and rock outcrop reduced by $38.67 \mathrm{Km}^{2}$ and 3.66 $\mathrm{Km}^{2}$ respectively.

Increase in wetlands and rock outcrop during the 19861999 may be as a result of land gain from expansion of the city, while the increase in wetlands during the 2009-2019 period can be attributed to the loss of vegetation and rock outcrop during that period especially with blasting of rocks which can open up more water channels, lead to increase in its volume and more spread to other parts. Loss of wetlands in the 1999-2009 period, rock outcrop in the 1999-2009 and 2009-2019 periods and that of vegetation in the 1986-1999 and 2009-2019 periods can be attributed to increase in built up during the study periods.

Figures $3 \mathrm{a}, \mathrm{b}, \mathrm{c}$ and $\mathrm{d}$ shows as revealed from the study evidence of developments along river banks, figure $3 \mathrm{c}$ shows some refuse dumped on the set back to the river. This shows that wetlands in the study area are being encroached upon.

The implication of this is that when there is heavy rainfall, the water levels will rise and flow to the river banks where these developments are sited leading to problems such as flooding which could bring with it loss of lives and properties depending on its intensity, structural damages and loss of habitat for wetland animals among others; environmental degradation, air and water pollution. Development along the river banks also implies loss of green areas in the form of vegetation which plays important roles in climate change mitigation, urban storm water runoff and ecosystem services as a whole among others; cultivation of crops which can help provide food and income for the increasing population in the study area. There is therefore a need to monitor developments along the river banks in the area. 


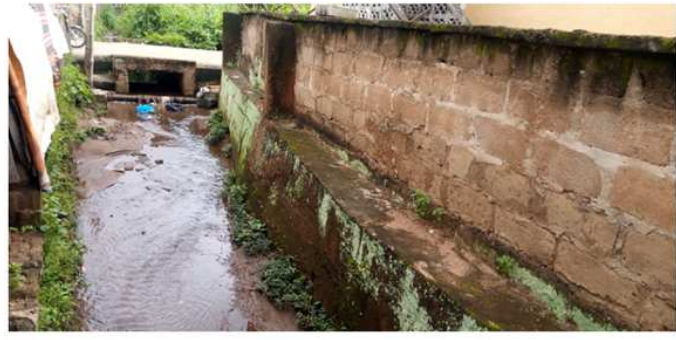

a

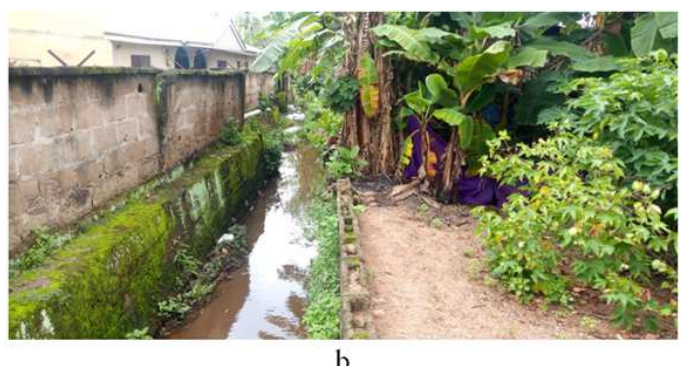

b

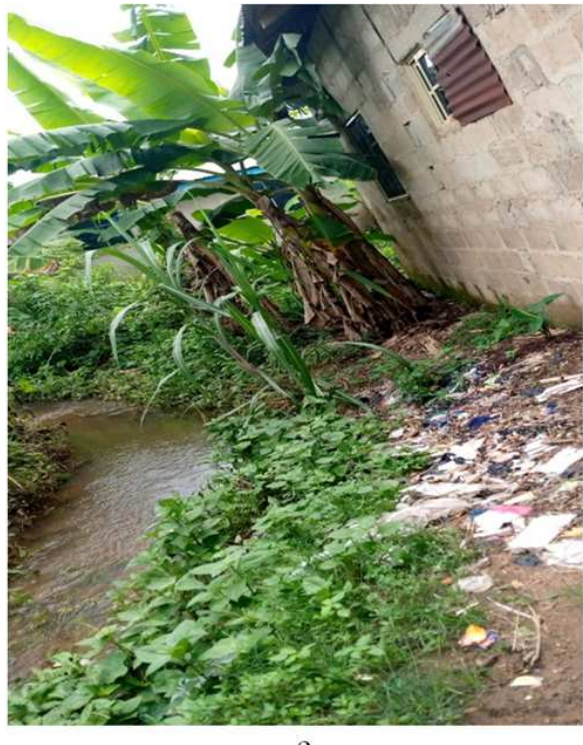

c

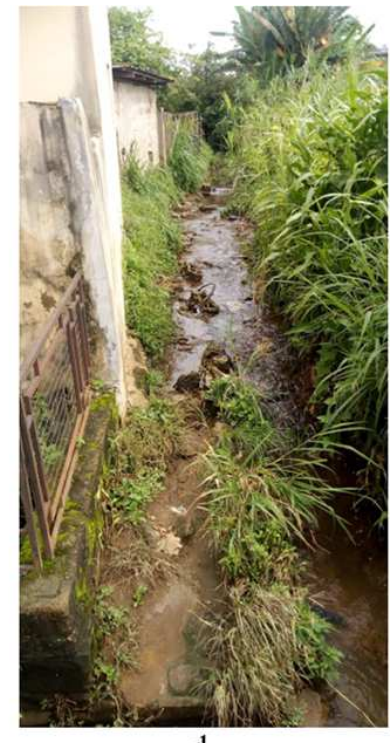

d

Author's field work, 2021.

Figure 3. $a, b, c$, : Pictures showing development along river banks in the study area.

\section{Conclusion}

The study revealed a rapid increase in built up areas in Akure South Local Government Area of Ondo State from 14.06 in 1986 to 63.28 in 2019 and gives a clear indication that the activities of man on the environment has brought about in the area which has led to changes in the spatial configuration of landuse/landcover types. This expansion if not properly monitored and controlled will lead to more changes through encroachment of other land uses especially wetlands which becomes degraded thereby affecting the quality of the environment. This assertion is supported by [11] who stated that the disappearance of arable lands, bare lands, water bodies and forest reserves have impacts on environmental and landscape attributes such as the quality of air, land and water resources, poverty, access to food and ecosystems processes and functions. [10] also affirmed that wetland degradation in Akure is as a result of Urban sprawl, expansion of roads, growth of informal settlements and noncompliance with planning regulations.

\section{Recommendation}

The study recommends that policies which will guide development of wetlands in the study area should be formed while the Ministry of Urban and Regional Planning should monitor and control developments enforcing strict compliance to the policies. Enlightenment programs that border on topics like the dangers of wetlands encroachment and degradation and benefits of wetlands should be organized for the residents. The study also recommends that wetland areas be turned to green belts where there can be wetlands vegetation or wetlands agriculture to improve the quality of the environment and livelihoods of the people.

\section{References}

[1] Cassidy, E. (2019). Map of the month: where are the world's wetlands? Resource watch Blog. https://blog.resourcewatch.org/2019/04/17/map-of-the-monthwhere-are-the-worlds-wetlands/

[2] Dauda, A. B. (2014). Salvaging wetland ecosystem in Nigeria: Towards ensuring sustainable fish production. Journal of Nature and Science 12 (9), 61-67.

[3] Gannaway, N. (1995). Sustainable wetlands development. Adapted from an article by Dr Sansanee Choowaew of Mahidol University, Thailand. Tiempo 18.

[4] International Training of Trainers on Wetland Management, (2009). Wageningen, Netherlands: Author.

[5] Millennium Ecosystem Assessment, (2005). Ecosystems and human well-being: Current state and trends. Island Press.

[6] Mohammed, G. B. (2013). Living on the edge, Nigeria. World Wetland Day (WWD) celebration organized by the Nigerian Conservation Foundation Living on the Edge Project (LotE) sponsored by Aage Jensen Charity Foundation in partnership with Birdlife International under the Wildlife Club of Africa Phase II Project.

[7] National Population Commission of Nigeria (2006). The 1991 Census: Federal Republic of Nigeria.

[8] Narayan, S., Beck, M. W., Wilson, P. et al. (2017). The Value of Coastal Wetlands for Flood Damage Reduction in the

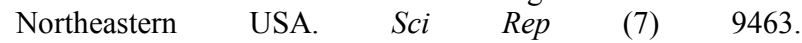
https://doi.org/10.1038/s41598-017-09269-z

[9] Numbere, A. O. (2020). The impact of landscape reclamation on mangrove forest and coastal areas in the Niger Delta, Nigeria in L. Loures (ed.), Landscape reclamation- Rising from what's left. https://doi.org/10.5772/intechopen.82053 
[10] Olajuyigbe, A. E., Adegboyega, S. A., Popoola, O. O. \& Olalekan, O. A. (2016). Assessment of rapidly changing urban land use and environmental degradation in Akure, Nigeria using satellite imagery and GIS techniques. Journal of Geography and Development 6 (1), 660-681.

[11] Omodehin, A. O. (2018). Urbanization and changes in landuse/landcover patterns in Akure, Nigeria. In cities of developing nations: the Akure example. In O. B. Akinbamijo, E. E. Okoko, F. K. Omole \& O. O. Popoola (eds.), The Just City: Poverty, deprivation and alleviation strategies. 218-228. YEMPET Prints Ltd.

[12] Orimoogunje, O., Oyinloye, R. \& Soumah, M. (2009). Geospatial mapping of wetlands potential in Ilesa, Southwestern Nigeria. In Municipality and Natural Resources Management working week, 2009, Surveyors key role in accelerated development. Eilat, Israel.

[13] Ramsar Convention Bureau, (2002). Cultural aspects of wetland. http://www.ramsar.org/sites/default/files/documents/library/co p10_culture_group_e.pdf.

[14] Ramsar Convention on Wetlands. (2018). Global Wetland Outlook: State of the World's Wetlands and their Services to People. Ramsar Convention Secretariat.

[15] Ramsar Convention Secretariat (2016). An Introduction to the Ramsar Convention on Wetlands, 7th Ed. (previously The Ramsar Convention Manual). Author.
[16] Ramsar Convention Secretariat, (2018). Wetlands: Essential for a sustainable urban future. Author, accessed from www.ramsar.org/library.

[17] Tijani, M. N., Olaleye, A. O. \& Olubanjo, O. O. (2011). Impact of urbanization on wetland degradation: A case study of Eleyele wetland, Ibadan, South West, Nigeria, Proceedings of the Environmental Management Conference, Federal University of Agriculture, Abeokuta, Nigeria. (pp. 438-457).

[18] Uluocha, N. O. \& Okeke, I. C. (2004). Implications of wetlands degradation for water resources management: Lessons from Nigeria. Geojournal 16, 151-154.

[19] United Nations (2015). Transforming our world: The 2030 Agenda for Sustainable Development. A/RES/70/1. https://www.sustainabledevelopment.un.org

[20] United States Environmental Protection Agency (2018). Wetlands. https://www.epa.gov/wetlands/what-wetland

[21] Wetlands International (2020).

[22] WWT Consulting (2018). Good Practices Handbook for Integrating Urban Development and Wetland Conservation. Slimbridge.

[23] Xu, T., Weng, B., Yan, D., Wang, K., Li, X., et al. (2019). wetlands of importance: Status, threats and future protection. International Journal of Environmental Response and Public Health 16 (10): 1818. https://doi.org/10.3390/ijerph16101818 